\title{
A Lossless Compression Method of Time-Series Data Based on Increasing Average of Neighboring Signals
}

\author{
Tetsuya Takezawa Non-member (NIPPOn TELEGRAPH AND TELEPHONE WEST CORPORATION) \\ Koichi Asakura Non-member (Nagoya University, asakura@watanabe.ss.is.nagoya-u.ac.jp) \\ Toyohide Watanabe Member (Nagoya University, watanabe@watanabe.ss.is.nagoya-u.ac.jp)
}

Keywords: lossless compression, time-series data, Golomb-Rice coding

Time-series data are sequences of attribute values which are sampled at appropriate intervals, such as audio data, movie data, sensor data of a car, and so on. Development of data compression methods for time-series data is very important to handle time-series data effectively. Reducing consumption of expensive resources such as disk space, transmission bandwidth and so on, can be achieved by the time-series data compression.

Golomb-Rice coding is a well-known lossless compression algorithm for time-series data. Golomb-Rice coding can handle a signal of which the absolute value of a amplitude value is small. In order to shorten the code length of signals, methods for reducing absolute values of a differential signal were proposed actively until now. These methods utilized past similar signals or predicted signals for generating differential signals. However, these traditional methods cannot handle the signal of which absolute amplitude values are increased drastically like a pulse signal. In other words, the absolute values of a signal cannot be decreased enough, since past signals or predicted signals are not similar to the signal. In our research, the purpose is that the signals of which absolute values are increased drastically are compressed effectively by generating the differential signals on the basis of GolombRice coding.

In our approach, the signal which increases neighboring average of a pulse signal is adopted as a reference signal. By using the reference signals, the changes of absolute values can be modest. The effectively generating differential signals is achieved based on not only reducing the absolute values of the differential signal but also increasing the neighbor average of the pulse signal. In this paper, we propose a method which selects an effective reference signal focused on increasing the neighbor average of a pulse signal on the basis of cumulative distribution features.

Fig. 1 shows a processing flow of our data compression procedure. Our algorithm consists of three steps as follows.

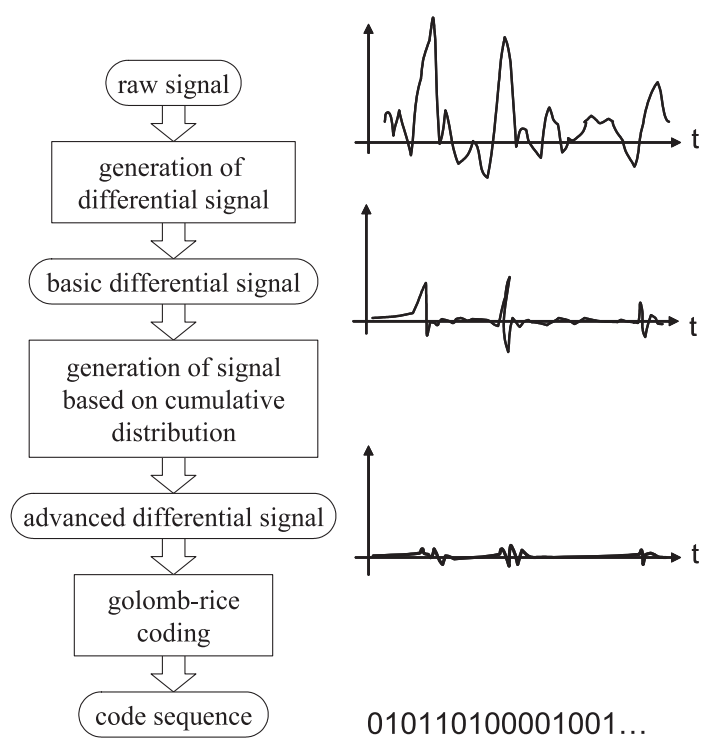

Fig. 1. Processing flow

(1) A differential signal is generated using the signals which appeared just before.

(2) An advanced differential signal is generated using the reference signals.

(a) The signal whose absolute value of amplitude is large, is detected by using a moving average method.

(b) A reference signal is selected based on the cumulative distribution features.

(3) A code sequence is generated based on the GolombRice coding.

As a result of our experiment, we confirm that our proposed method can generate codes whose length is shortened. The code length is decreased to $97 \%$ on average and up to $81 \%$ in comparison with the traditional method. 


\title{
近傍平均值の増大に着目した時系列データ可逆圧縮
}

\author{
非会員 竹澤 哲矢* 非会員 朝倉 宏一** \\ 正 員 渡邊 豊英**
}

\begin{abstract}
A Lossless Compression Method of Time-Series Data Based on Increasing Average of Neighboring Signals
\end{abstract}

Tetsuya Takezawa*, Non-member, Koichi Asakura**, Non-member, Toyohide Watanabe**, Member

Golomb-Rice coding is a well-known compression algorithm for sensor data. When time-series data changes drastically with the large amplitudes such as a pulse signal, the code length based on Golomb-Rice coding becomes very long. In order to shorten the code length, amplitude of signal is decreased by calculating differential signal between a raw signal with a similar signal. In this paper, we develop a lossless compression method for time-series data such as sensor data. In traditional methods, finding the past-signal from which a differential signal with low amplitude can be generated is the main topic. However, if there are no past-signals to reduce sufficiently the amplitude of differential signal, the data compression procedure takes only low effects. In our approach, a signal which decreases energy of a pulse signal or increases energy of the neighboring signal of a pulse signal is adopted to generate differential signals. In order to select an effective signal, we propose a method for detecting reference signals based on cumulative distribution features of time-series data. As results of experiments, we confirm that our proposed method can generate codes whose length is shortened. The code length was decreased to $97 \%$ on average and up to $81 \%$ in comparison with the traditional method.

キーワード : 可逆圧縮, 時系列データ, Golomb-Rice 符号化

Keywords: lossless compression, time-series data, Golomb-Rice coding

\section{1. はじめに}

時系列データとは，ある時間間隔でサンプリングされた 特性值列を指す。例として, 楽曲に代表される音声データ, 映画やテレビ番組などの動画像, 対象の特性を得るための 観測デー夕など（自動車のセンサー, 株価, 気象情報, 星 像など(1)）がある。時系列デー夕を計算機で効率よく扱う ためには，時系列データのサイズを縮小させる時系列デー 夕圧縮技術が重要となる。時系列デー夕圧縮により, 記憶 容量や通信容量などを節約することができ，より多量の情 報をより高速に扱うことができる。

\footnotetext{
*西日本電信電話株式会社

大阪府 大阪市 中央区 馬場町 3-15

NIPPON TELEGRAPH AND TELEPHONE WEST CORPORATION

3-15, Banba-cho, Chuo-ku, Osaka

** 名古屋大学大学院 情報科学研究科 社会システム情報学専攻 愛知県 名古屋市 千種区 不老町

Department of Systems and Social Informatics, Graduate School of Information Science, Nagoya University

Furo-cho, Chikusa-ku, Nagoya
}

観測データなどの時系列データを可逆圧縮する方法と して, Golomb-Rice 符号化手法がよく知られている ${ }^{(2)(3)}$ 。 Golomb-Rice 符号化手法は, 時系列データを構成する数值 の絶対值が小さい場合に高圧縮を実現できる。一方, 絶対 值が急激に変化する信号を圧縮すると, 圧縮後の符号が長 くなるという問題がある。この問題に対処するため, 予測 信号や過去の信号との差分を利用し, 信号の絶対值やエネ ルギーを低減させる手法が提案されてきた (1)(4)(5)。しかし, これらの提案にはパルス信号に対しては圧縮の効果が低い という問題があった。センサーでの観測データには，緩や かな変動の中に短区間の急激な変動が現れるという特性が あり，時系列データの圧縮においては，パルス信号のよう な急激な変動に対してどのように対処するかが重要である。

本稿では，センサーによる観測データを代表とする時系 列データを可逆圧縮する方法として, Golomb-Rice 符号化 手法に基づき，急激に変動する信号を残差処理により圧縮 する手法を提案する。残差処理において,より効果的な圧 縮を実現するためには参照信号の選択基準が重要である。 本稿では, 時系列データの累積分布特徴を用いて, 参照信 号を選択する手法を提案する。本手法を用いることにより， 
絶対值の低減に基づく既存手法と比較して，圧縮時の符号 を短くすることが可能となる。

本稿の構成は以下のようである。2 章では, 関連研究を まとめ，問題点を明らかにする。3 章では，参照信号選択 に対するアプローチを述べる。 4 章では，我々が提案する 時系列デー夕圧縮のアルゴリズムを述べる。5 章では提案 手法の有効性を示すための実験と考察を示す。6 章で本稿 をまとめる。

\section{2. 関連研究}

本章では，時系列デー夕圧縮の基本手法となる GolombRice 符号化の原理と特徵について述べ，次に符号長を短 くするために信号のエネルギーを低減する手法について述 ベる。

$\langle\mathbf{2} \cdot \mathbf{1}\rangle$ Golomb-Rice 符号化 Golomb-Rice 符号化 は，時系列デー夕に対して有効な符号化手法である (2) (3)。 Golomb-Rice 符号化処理のアルゴリズムを Fig. 1 に示す。 まず，記号 (数值) が正なら 2 倍し，負なら-2 倍して 1 を 引く。この処理により, 数值列の全ての值が正となり, 偶 数か奇数かにより元記号の正負を判断できる。その記号を 2 進数に変換する。近傍平均值の桁数より大きい桁を連長 圧縮法（ランレングス圧縮法）を用いて符号化し，近傍平 均值の桁数より小さい桁はそのまま符号にする。近傍平均 值 ave $_{i}$ は次式によって与えられる。

$$
\text { ave }_{i}=\frac{1}{\alpha} \sum_{j} \begin{cases}x_{i-j} & \left(1<j \leq \frac{1}{2} \alpha\right) \\ \frac{x_{i-j}}{2} & \left(\frac{1}{2} \alpha<j \leq \frac{3}{4} \alpha\right) \\ \vdots & \vdots \\ \frac{x_{i-j}}{\alpha} & (j=\alpha)\end{cases}
$$

ここで， $x_{i}$ は $i$ 番目の記号， $\alpha$ は近傍の範囲を決定する閾 值である。

Golomb-Rice 符号化では，近傍平均值の違いにより，同 じ数值でも符号化後の符号長が大きく異なる。その違いを， “50” という数值の符号化処理を例として，Fig. 2 に示す。 “50”を最初に 2 倍して 100 とし, 2 進数化して $(1100100)_{2}$ を得る。ここで，近傍平均值を 2 進数表現したときの桁数 が 5 桁のときの符号化処理を Fig. 2(a) に，近傍平均值が 0 のときの符号化処理を Fig. 2(b) に示す。Fig. 2(a) では，6 桁以上に対して連長圧縮が適用され，5桁以下はそのまま 符号として利用される。すなわち，(11) 2 を連長圧縮処理 により“0001”と符号化し，5桁以下はそのまま利用され るので，最終的に“000100100”の 9 ビットの符号が得ら れる。これに対して，Fig.2(b)では，すべての桁が連長圧 縮されるので，“00…001”という 101 ビットの符号が生 成される。このように，Golomb-Rice 符号化には，記号の 桁数が急激に変化するとき，符号長が非常に長くなるとい う問題点がある。

$\langle\mathbf{2} \cdot \mathbf{2}\rangle$ 絶対值の低減 上記の問題を解決するために, 信号の絶対值を低減させる手法が提案されている。類似信 号との差分処理により絶対值を低減させることが基本的な

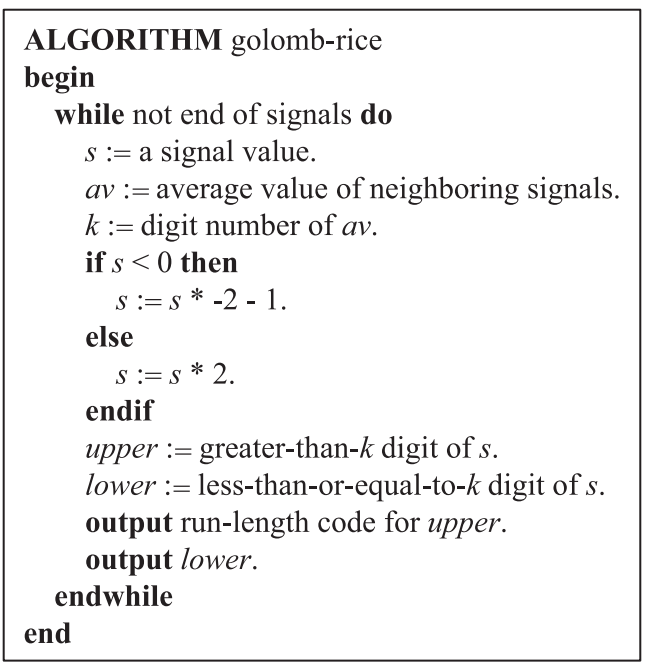

Fig. 1. An algorithm of Golomb-Rice coding
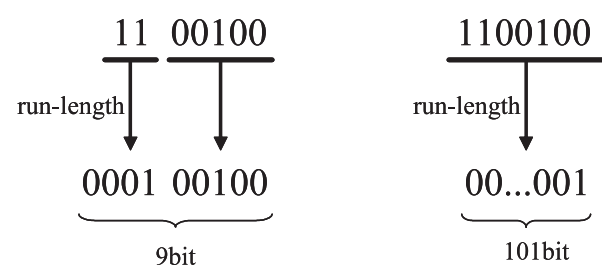
(a) $\mathrm{k}=5$
(b) $\mathrm{k}=0$

Fig. 2. Examples of Golomb-Rice coding

考え方であり, 過去数点分の信号から次に現れる信号の值 を予測する手法 ${ }^{(4)(5)}$ や，過去の信号や他チャネルの信号 から類似信号を検出する手法 (1) (4) (5) が報告されている。

前者の手法では，過去数点分の值から次の信号值を補外 法などにより予測し，その予測值と信号值の差分処理によ り, 絶対值を低減させる。周期的な時系列データや変化の 少ないデー夕など, 過去の系列から次の信号值が精度よく 予測可能なときは効果的であるが，上記で述べたようなパ ルス信号の系列データに対しては有効でない。

後者の手法では，類似した過去の系列データとの差分処 理により絶対值を低減させる。ここで，類似信号との差分 処理により生成された信号を残差信号と呼び，そのときに 用いる過去または他チャネルの信号を参照信号と呼ぶ。残 差信号は次式によって表される。

$$
z_{t}=x_{t}-r \times y_{t}
$$

このとき， $z_{t}$ は残差信号， $x_{t}$ は元の信号， $y_{t}$ は参照信号で ある。また, $r$ は残差信号の二乗ノルム $|z|^{2}$ を最小化する 係数であり，以下のように計算される。

$$
r=\frac{\boldsymbol{x}^{T} \times \boldsymbol{y}}{\boldsymbol{y}^{T} \times \boldsymbol{y}}
$$

ここで, $\boldsymbol{x}^{T}$ はベクトル $\boldsymbol{x}$ の転置を表す。残差信号から元 の信号に復元するためには，参照信号の位置，係数 $r ，$ 記 号の長さの 3 種類のデータを付加する必要がある。符号長 
を短くするためには，どの参照信号を利用するか，すなわ ち参照信号を選択する基準が重要である。参照信号の選択 には，一般的に残差信号エネルギーに基づく手法が用いら れる。すなわち，残差信号のエネルギー

$$
e=\sum_{i} z_{i}^{2}
$$

が最小となる参照信号を選択する。

\section{3. アプローチ}

残差信号を生成して信号値の絶対値を低減させる方法に 基づき Golomb-Rice 符号化の問題点を解決する方法とし て，過去の信号系列から次に現れる信号の值を予測する手 法や，過去の信号や他チャネルの信号から類似信号を検出 する手法について述べた。これらの処理により一般的に工 ネルギーの低い残差信号を得ることができる。しかし，突 発的に現れるパルス信号に対しては，これらの処理によっ てエネルギーを十分に低減させることが難しいという問題 がある。この問題点を Fig. 3 に示す時系列デー夕を用いて 説明する。Fig. 3 には, 残差処理により得られた二種類の 信号が表されている。信号 A は小さい值 (100) が連続して 現れた後，大きい值 (900) が現れている。それに対し，信 号 B では連続して現れる小さい值 (0) が信号 A と異なって いる。この二種類の信号のエネルギーと Golomb-Rice 符 号化を適用したときの符号長を Table 1 に示す。この表か ら，残差信号のエネルギーは信号 B の方が小さいが，符号 化後の符号長は大きく異なり，信号 $\mathrm{A}$ の方が短いことが分 かる。これは，信号 A に連続して現れる小さい值 (100)に よって近傍平均值が増加しているため, 大きい值 (900) と の桁数の差が小さくなることで生じた差である。以上より， パルス信号に対して Golomb-Rice 符号化手法を効率よく 適用するためには，信号の絶対值を低減させる残差処理を 適用するとき，残差信号のエネルギーではなく，残差信号 の近傍平均值を考慮に入れて参照信号を選択することが有 効であることが分かる。

我々は残差信号の絶対值低減に加え，パルス信号の近傍 平均值の増大に着目し，効果的な残差処理を実現する。残 差信号の近傍平均值を考慮に入れた参照信号選択の方法と して，累積分布特徴を用いた手法について述べる。

〈3.1 〉 累積分布特徵 参照信号を選択するとき，残 差信号の絶対值を低減させること，および残差信号におけ るパルス信号の近傍平均值を増大させることを両立させる 必要がある。残差信号の絶対值を低減させるには，従来の ようにエネルギーが最小となる参照信号を選択することで ある程度達成できる。しかし，パルス信号に対しては，近 傍平均值を増大させることが効果的であり，従来の方法で はそれを満たす参照信号を検出することができない。

両者を両立させる参照信号の検出指標として，我々は累 積分布特徴を用いる。累積分布特徵とは，信号の絶対値に 対する累積分布から，適当な周期 $M$ でサンプリングした 数值列を表す。Fig. 4 に累積分布特徵の生成アルゴリズム

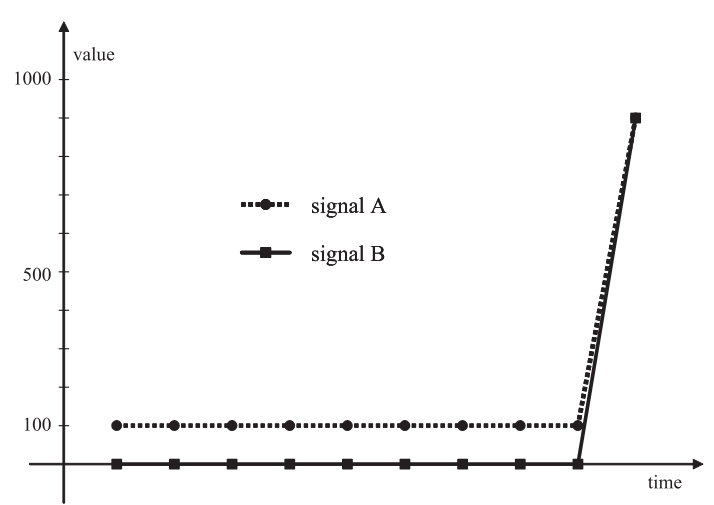

Fig. 3. Sample signals

Table 1. Energies and code lengths

\begin{tabular}{|l|r|r|}
\hline & Energy & Code length [bit] \\
\hline singal A & 17,100 & 300 \\
signal B & 8,100 & 1,800 \\
\hline
\end{tabular}

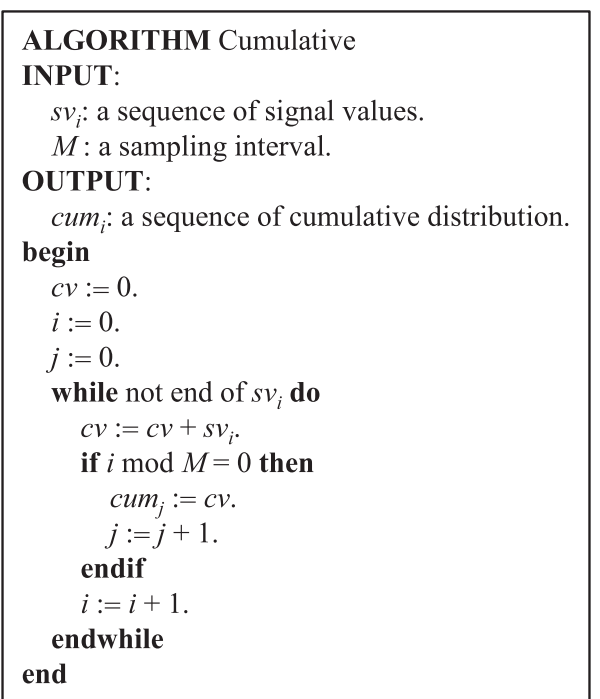

Fig. 4. An algorithm of calculating cumulative distribution

を示す。 $M$ の值は, 対象とする信号の高周波数特徴をどの 程度累積分布特徵に反映させるかにより決定される。累積 分布特徵を用いることにより，エネルギーを最小化するパ ルス型の参照信号と同様に，エネルギーが分散し近傍平均 值を増大させる効果のある参照信号も検出することができ る。したがって，パルス信号でない通常の信号に対しては 残差信号のエネルギーを最小にする参照信号を，パルス信 号に対しては近傍平均值を増大させるエネルギーが分散し た参照信号を，それぞれ検出することができる。そのため， 残差信号のエネルギーを最小とする参照信号を選択する手 法と比較して, Golomb-Rice 符号化手法を効率よく適用可 能な残差信号を出力することが可能となる。

\section{4. 累積分布特徵を用いた信号圧縮}

本章では，累積分布特徴を用いた信号圧縮の手法につい 


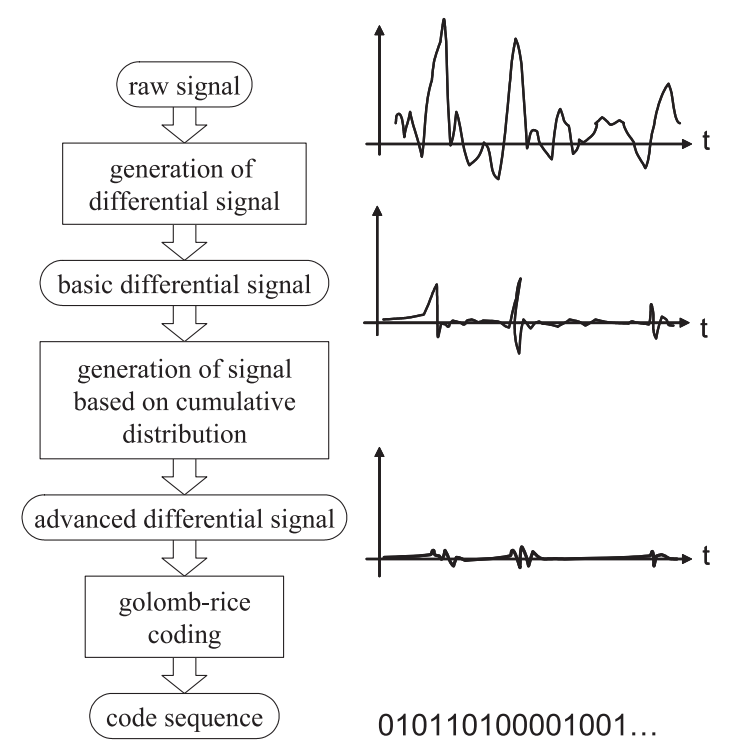

Fig. 5. Processing flow

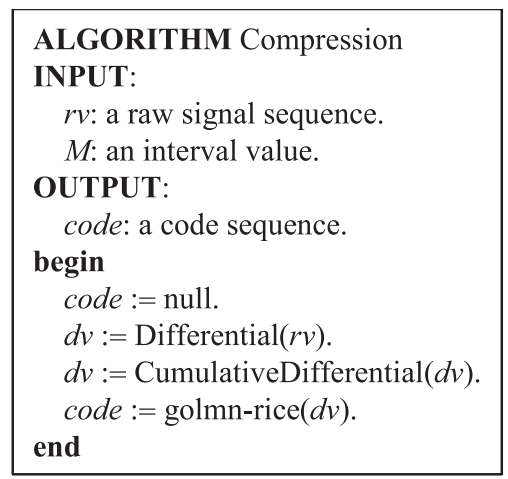

Fig. 6. Our proposed algorithm

て述べる。Fig. 5 に信号圧縮の概要を，Fig. 6 に信号圧縮 アルゴリズムを示す。本手法は 4 ステップ，すなわち，

（1）差分信号生成処理,

（2）累積分布特徵に基づく参照信号選択処理,

(3) 残差信号生成処理,

(4) Golomb-Rice 符号化処理, からなる。このうち，本手法において特徵的な差分信号生 成処理と，累積分布特徵に基づく参照信号選択処理につい て，以下それぞれ述べる。

$\langle\mathbf{4} \cdot \mathbf{1}\rangle$ 差分信号生成処理 $\langle 2 \cdot 2\rangle$ 節において，予測信 号を用いて信号絶対值を低減する手法について述べた。我々 は予測信号として 1 時刻前の信号を採用する。すなわち, 入力信号 $x_{t}$ に対する差分信号生成処理として,

$$
x_{t}^{\prime}=x_{t}-x_{t-1}
$$

の計算を施し， $x_{t}^{\prime}$ を続く処理の対象信号とする。ここで， 1 時刻前の信号との差 $x_{t}^{\prime}$ を差分信号と呼ぶ。Fig. 7 に差分 信号生成処理のアルゴリズムを示す。

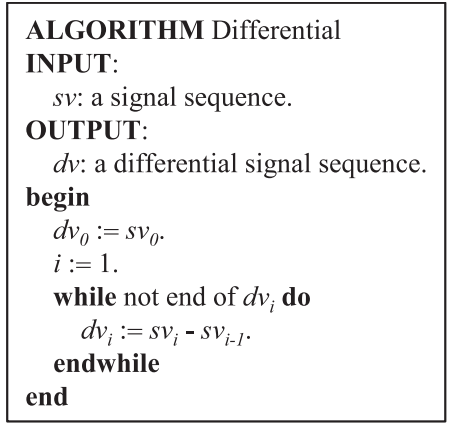

Fig. 7. An algorithm for generating differential signals

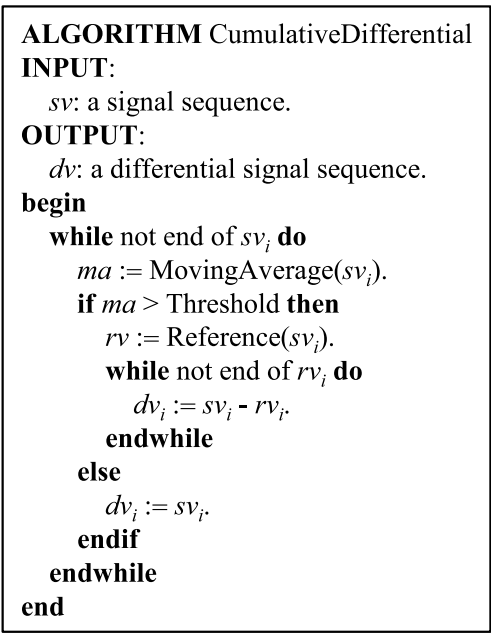

Fig. 8. An algorithm for selecting the reference aignal

信号を選択し残差信号を生成する必要があるのは，入力信 号の絶対值が大きい場合である。すなわち，入力信号の絶 対值が小さい場合は, 残差信号を生成せずそのまま符号化 する方が，残差信号生成した場合と比較して，生成される 符号長が短くなる†。したがって, まず入力信号の絶対值に より残差信号を生成するか否かを決定し，残差信号を生成 する場合は，累積分布特徴を計算して参照信号を選択する。

Fig. 8 に，累積分布特徵に基づいた参照信号選択処理の アルゴリズムを示す。以下，入力信号の絶対值により残差 信号を生成するか否かの条件分岐処理と, 参照信号の選択 処理について具体的に述べる。

$\langle\mathbf{4} \cdot \mathbf{2} \cdot \mathbf{1}\rangle$ 残差信号生成処理の起動条件 累積分布特 徵から参照信号を選択して残差信号を生成するとき，その 処理に必要な計算コストと, その復号化に必要となる付加 的なデー夕に関する検討が必要となる。本アルゴリズムで は，移動平均に基づいて残差信号生成処理を起動するか否 かを決定する。移動平均值 $a_{i}$ は次式によって表される。

†残差信号を生成したとき，残差信号を生成したときに利用した参 照信号に関する情報などが付加的に必要となり，それらの情報により 逆に符号長が長くなる場合がある。 


$$
a_{i}=\sum_{k=i-W}^{k=i+W} \frac{x_{k}^{\prime}}{2 W+1}
$$

ここで, $W$ は移動平均として利用する前後の点の数を, $x_{k}^{\prime}$ は差分信号を表す。 $a_{i}$ がしきい值以上となったとき，残差 信号生成処理が実行される。

\section{$\langle\mathbf{4} \cdot \mathbf{2} \cdot \mathbf{2}\rangle$ 累積分布特徴による参照信号選択処理}

$\langle 4 \cdot 2 \cdot 1$ 節で述べた条件が成立したら，累積分布特徽を 生成し参照信号を選択する。 $x_{i}^{\prime}$ から開始される長さ $L$ の信 号の絶対值に対する累積分布 $f_{L}(i)$ は以下のように定義さ れる。

$$
f_{L}(i)=\sum_{j=0}^{L}\left|x_{i+j}^{\prime}\right| \ldots \ldots \ldots \ldots \ldots \ldots \ldots \ldots \ldots \ldots \ldots \ldots \ldots \ldots
$$

この累積分布を正規化し， $M$ 点間隔でサンプリングす ることで，累積分布特徵を得ることができる。時刻 $i$ か ら開始される長さ $N$ の信号に対する累積分布特徵 $V=$ $\left(v_{1}, \cdots, v_{k}, \cdots, v_{N / M}\right)($ ただし, $N \bmod M=0)$ は, 次 式によって与えられる。

$$
v_{k}=\frac{f_{M \times k}(i)}{f_{N}(i)} \quad(k=1, \cdots, N / M)
$$

計算した累積分布特徵を過去の信号の累積分布特徵と比 較することで，参照信号を選択する。二つの累積分布特徵 の類似度は，ユークリッド距離を用いて計算される。入力 信号の累積分布特徵 $V_{s}$ と過去の信号の累積分布特徴 $V_{p}$ の ユークリッド距離は,

$$
d=\sqrt{\sum_{i=0}^{N / M}\left(v_{s i}-v_{p i}\right)^{2}}
$$

と表される。 $d$ が最小となる $V_{p}$ が参照信号として選択さ れる。

参照信号が選択された後，時刻 $i$ と $V_{s}$ が，新たに参照 信号候補として保存され，次に続く処理で利用される。

$\langle\mathbf{4} \cdot \mathbf{3}\rangle$ 提案アルゴリズムの性質 本節では, 差分信 号を生成するための参照信号を探索する方法として，従来 手法であるエネルギー差分を用いた手法と, 提案手法であ る累積分布を用いた手法について, 計算量とメモリ使用量 の観点から考察する。

$\langle 4 \cdot 3 \cdot 1\rangle$ 計 算量 従来手法, 提案手法とも, 処理 の流れは同様であり，

（1）特徴量の計算,

（2）特徵量を用いた参照信号の探索,

（3）参照信号を用いた差分信号の計算,

である。ここで, 差分信号の計算処理はどちらも同一であ

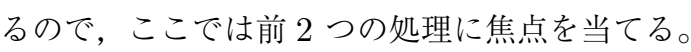

特徽量の計算処理に対しては, 従来手法では (4) 式が, 提 案手法では (7)，(8) 式が，それぞれ対応する。差分処理対 象信号の信号長 $L$ を用いると，従来手法は $O(L)$ の計算量 である。それに対し，提案手法では，式の定義をそのまま
用いれば (7) 式は $O\left(L^{2}\right),(8)$ 式は $O(L)$ となるが, $(7)$ 式 は漸進的に計算可能であるので, $O(L)$ で計算可能である。 したがって, 提案手法の計算量は $O(2 L)$ となる。また, 参 照信号の探索処理に関しては，従来手法では差分信号を生 成し，そのエネルギー量を計算するので，参照信号の個数 を $R$, 参照信号の長さを $L^{\prime}$ とすれば, 計算量は $O\left(l^{\prime} \cdot R\right)$ となる。それに対して, 提案手法では累積分布の比較処理 となるので, 計算量は $O\left(\frac{N}{M} \cdot R\right)$ となる。参照信号の長さ を $L^{\prime}$ に正規化すれば，提案手法と従来手法は同じ計算量と なる。

上記の分析より, 定性的には, 従来手法, 提案手法とも, $L, R$ に対する計算量の変化の性質はほぼ同様である。し かし, 提案手法は従来手法に比較して, $O(L)$ に対応する 計算時間が余分に必要となり, この計算時間の増加と圧縮 率のトレードオフが重要となる。

$\langle\mathbf{4} \cdot \mathbf{3} \cdot \mathbf{2}\rangle \times$ メリ使用量 参照信号の探索のためには， $R$ 個の参照信号候補の特徵量をあらかじめ計算し格納する 必要がある。特に, 提案手法で用いる累積分布の計算には 時間がかかるので, すでに計算した累積分布特徵を蓄積し 再利用することは合理的ではあるが，そのために使用メモ リ量が多くなる。ここで，保持する特徵量を，

従来手法：＜信号開始点, 信号終了点 $>$

提案手法: <信号開始点, 信号終了点, $<$ 累積分布 $>>$ としたとき，メモリ使用量は約 $2:\left(2+\frac{N}{M}\right)$ となる。した がって, 提案手法では少ない参照信号数で圧縮率の向上を 図ることが重要となる。

\section{5. 評価実験}

本章では，提案した压縮手法の有効性を確認するために 実施した評価実験について述べる。まず，提案手法の基本 的な性能を確認するため, 人工的に生成した時系列デー夕 を用いた予備実験を実施した。次に, 実際の時系列デー夕 を例として，様々な車載センサーから得られたデー夕を用 いて評価実験を実施した。実験パラメータとして， $\frac{N}{M}$ を 10, すなわち累積分布特徵を表すべクトルの長さを 10 と した。これにより, 提案手法のメモリ使用量が, 従来手法 の扮㧍よそ 6 倍となるので, 同メモリ量での性能評価のた め, 従来手法の $R$ を 120 に, 提案手法の $R$ を 20 に, そ れぞれ設定した。また， $L$ は信号により動的に可変し, 最 大で 200 とした†。

$\langle\mathbf{5} \cdot \mathbf{1}\rangle$ 予備実験 予備実験では, 人工的な時系列デー 夕を生成し，そのデー夕を

（1）差分信号のみを用いた手法,

（2）エネルギー量による参照信号選択アルゴリズムを 用いた手法,

（3）累積分布特徵による参照信号選択アルゴリズムを 用いた提案手法,

†移動平均值が閾值を超えた点を開始点, 閾值を下回った点を終了 点とし, $L=$ 終了点 - 開始点 +1 である。 


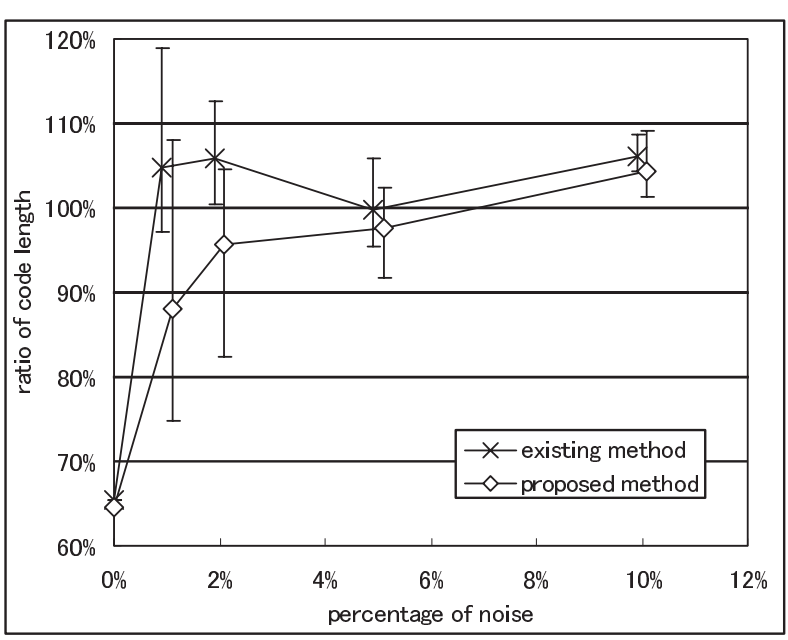

Fig. 9. Experimenal results for pseudo data

により圧縮し，圧縮後のコード長を比較した。まず基になる 時系列データとして，周期 50 ステップとした高さ 500 の パルス信号を生成した。その時系列デー夕に対して，パルス 高の $1 \%, 2 \%, 5 \%, 10 \%$ の白色雑音を印加した時系列デー 夕を 10 個ずつ生成し，圧縮後のコード長の平均值と最短・ 最長值を計測した。ここで, 残差信号生成処理の記号条件, すなわち（2），(3）の手法が起動される条件として，移動 平均值の計算時のパラメータ $W$ ，および移動平均值に対す るアルゴリズム CumulativeDifferential 中の閾值 Thres の值の設定は非常に重要である。本実験では， $W=4$ と し， 9 点の平均值を求め, パルス信号により (2), (3) の処 理が起動されるよう，閾值を 50 とした。(1）と（2），(3) の比較により残差信号処理の有効性を，(2) と（3）の比較 により参照信号選択基準の有効性を，それぞれ評価する。

実験結果を Fig. 9 に示す。グラフの横軸は印加した白色 雑音の割合を，縦軸は（1）の手法に対する $(2) ，(3)$ の手 法の生成コード長の割合を，それぞれ表している。眓を見る と, 雑音が $0 \%$ のとき，(2)，(3) どちらの手法もコード長 が約 $65 \%$ となっており, 残差信号処理の有効性が確認でき る。しかし雑音が $1 \%$ 印加されると，提案手法ではコード 長が約 $88 \%$ になっているのに対し，従来手法ではコード長 が 100\%を超え急激に長くなっていることが分かる。雑音に より近傍平均值が増大し，それにより参照信号として選択 される信号が異なった結果であることが分かる。この実験 結果により提案手法の有効性を確認することができる。雑 音の割合が大きくなるとコード長が長くなり，雑音が $10 \%$ となると（2），(3）ともほぼ同じコード長になっているが， 提案手法の方がより短いコードを生成していることが確認 できる。

上記の予備実験により，我々が提案した累積分布特徵を 用いた参照信号選択処理の有効性を確認することができた。

$\langle\mathbf{5} \cdot 2\rangle$ 評価実験 本節では, 実際の車載センサーか ら得られた時系列デー夕を対象として，提案手法の有効性 を確認する。利用した時系列デー夕の諸元を以下に示す。

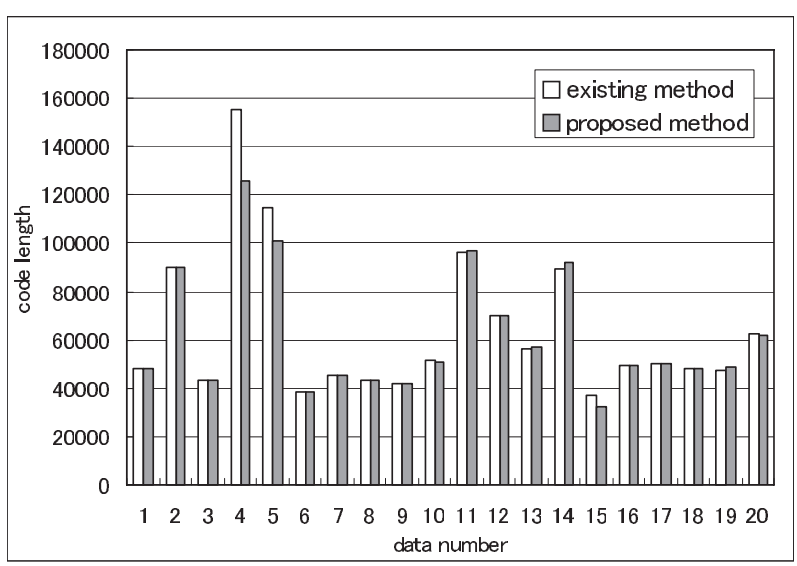

Fig. 10. Experimental results for sensor data

Table 2. Length of compressed codes

\begin{tabular}{|r|r|r|}
\hline & code length & ratio of code length \\
\hline \hline Method A & $1,370,769$ & - \\
Method B & $1,278,151$ & $93.2 \%$ \\
Method C & $1,234,535$ & $90.0 \%$ \\
\hline
\end{tabular}

$\begin{array}{ll}\text { 信号数: } & 119 \text { 個 } \\ \text { サンプリング: } & 0.01 \text { 秒間隔 } \\ \text { データ長: } & 10,000 \text { 点 (100 秒間 }) \\ \text { データ形式: } & \text { 整数 }\end{array}$

このデータのうち, 残差処理が起動した 20 個のデー夕を 用いて，エネルギー量を用いた従来手法と，累積分布を用 いた提案手法を用いて生成したコード長を比較した結果を Fig. 10 に示す。提案手法により符号の短縮化が図られたの は 20 個中 12 個だった。大幅に符号長が短くなったデー夕 を図より確認できる。また，5個は従来手法よりも符号長 が長くなったが，その差は数％であることも分かる。3 個 は同一符号長となった。

特に 4 番目のデー夕は圧縮効果が高く，提案手法の符号 長は既存手法の符号長の約 $81 \%$ に減少した。この入力信号 と, 従来手法, 提案手法による残差信号のうち, 特徴的な 部分をFig. 11 に示す。Fig. 11(a) では，信号の振幅が大き くなっている部分に対して, 従来手法, 提案手法の差分処 理により振幅を小さくすることができたことが分かる。ま た, Fig. 11(b),(c) では, 圧縮率を悪化させる大きな要因で あるパルス状の信号に対する処理結果を示している。提案 手法により，パルス信号が出現するの近傍の信号值が大き くなっていることが確認できる。このことより，近傍平均 值の増大が圧縮効率の向上に効果的であることが分かる。

一方, 提案手法の効果が最も低かった 14 番目のデー夕 では，提案手法の符号長は既存手法の符号長の約 $103 \%$ と なった。このデータの波形を Fig. 12 に示す。パルス状の 信号がほとんど発生しない場合は，既存手法による残差信 号のエネルギー低減の効果が明確であり，これにより符号 長が短くなったと考えられる。

すべてのデー夕に対して，差分処理（Method A)，既存 


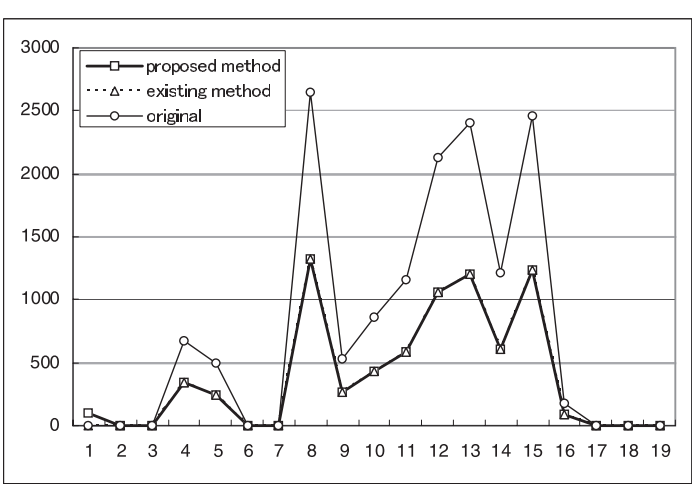

(a) Differential signals for normal signal sequence

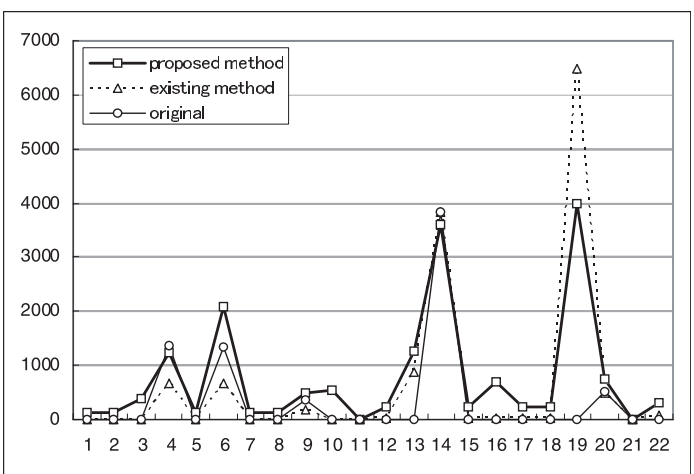

(b) Differential signals for pulse signal

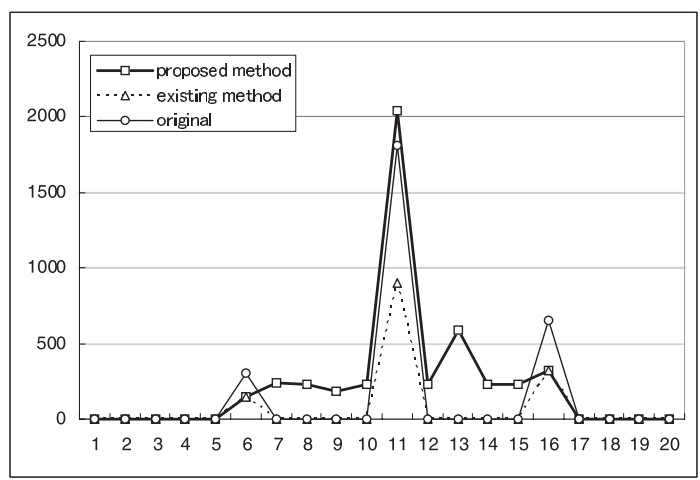

(c) Differential signals for pulse signal

Fig. 11. Sequences of signal (No.4)

手法による残差処理 (Method B)，提案手法による残差処 理（Method C）を用いて圧縮したときの符号長の合計を， Table 2 に示す。提案手法は，差分信号と比較すると約 $10 \%$ ，既存手法と比較すると約 $3 \%$ 符号長を短縮できた。また， 実行時間を比較すると，

従来手法： 0.86 秒

提案手法: 0.71 秒

となり，デー夕量と比較してそれほどの差はなかった。

以上より，パルス信号による圧縮率の低下に対して，本 稿で提案した累積分布特徵を用いた参照信号選択アルゴリ ズムが効果的であることが確認できた。

\section{6. おわりに}

本稿では，パルス信号の高圧縮を目的とした，時系列デー

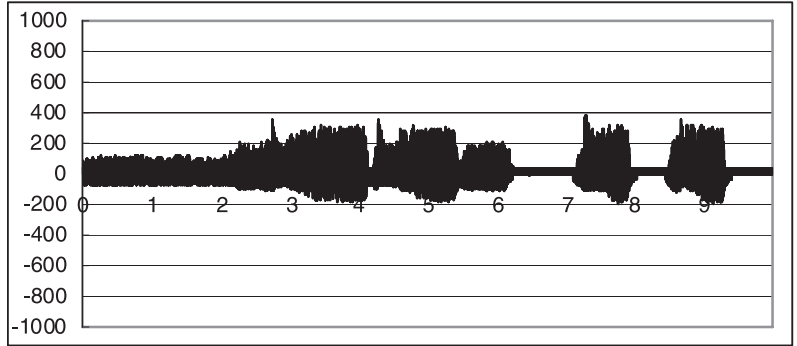

(a) Original dirrerential signal

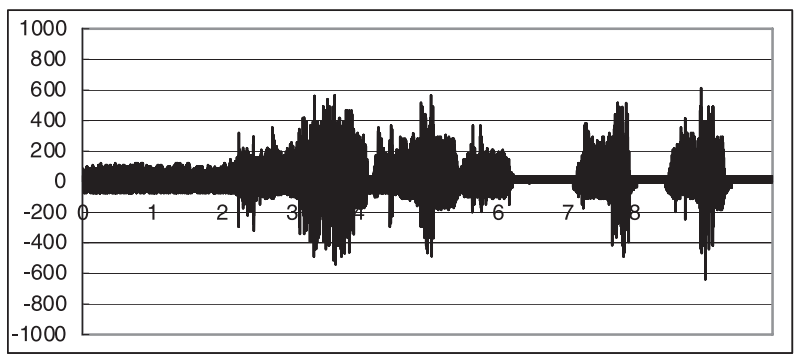

(b) Dirrerential signal with existing method

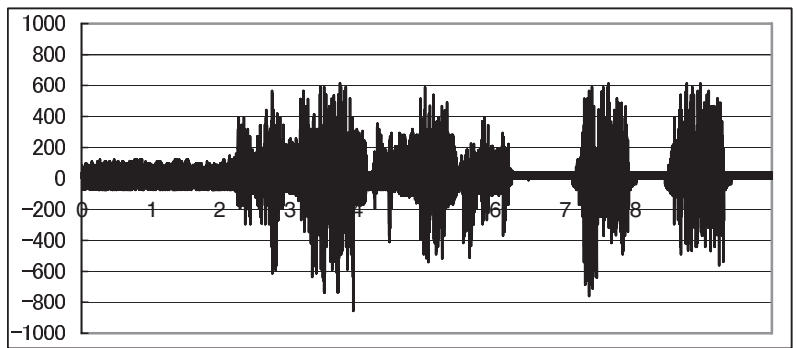

(c) Dirrerential signal with proposed method

Fig. 12. Overview of signal (No.14)

夕に対する可逆圧縮手法を提案した。パルス信号の近傍平 均值を増大させるというアプローチに基づき，累積分布特 徵を用いた参照信号選択アルゴリズムを提案した。従来の 残差信号エネルギーに基づいた参照信号選択アルゴリズム と比較して，符号長を約 $97 \%$ にすることができた。特に パルス信号が数多く含まれる信号に対しては，符号長が約 $81 \%$ になり，本手法の効果を確認することができた。

あまりパルス信号の含まれない信号の場合，既存手法の 方が計算コストが低く，圧縮率にはそれほど変化がなかっ た。また，今回の実験では，アルゴリズム中のパラメータは 一定であった。入力信号の特徵に合わせて，既存手法と提 案手法を選択的に利用したり，アルゴリズム中のパラメー 夕を変化させるなど，入力信号に適応する処理の実現によ り，さらなる圧縮を実現することが今後の課題である。

(平成 19 年 3 月 14 日受付, 平成 19 年 9 月 5 日再受付)

\section{文献}

（1）山田良透他：「JASMINE プロジェクトのためのデー夕压縮技術」, 国立天文台報，Vol.8，pp.15-20 (2005)

(2) R.F. Rice et al.: "Some Practical Universal Noiseless Coding Techniques", JPL Publication 79-22 (1979)

(3) S.W. Golomb et al.: "Run-length Encodings", IEEE Trans. 
on Information Theory, Vol.IT-12, No.3, pp.339-401 (2003)

（4）鎌本 優他：「チャネル間相関を用いた多チャネル信号の可逆圧縮 符号化」, 情処学論, Vol.46, No.5, pp.1118-1127 (2005)

(5) M. Hans te al.: "Lossless Compression of Digital Audio", IEEE Signal Processing Magazine, Vol.18, No.4, pp.21-32 (2001)

竹 澤 哲 矢 (非会員) 2005 年名古屋大学 工学部 電気電子. 情報工学科 卒業。2007 年 同大学大学院情報科学 研究科 社会システム情報学専攻 博士課程前期課 程修了。同年 西日本電信電話（株）入社。現在, ソリューション業務として，主にネットワーク系 のソリューションを提案・構築する業務に従事。 在学時, 時系列デー夕圧縮に関する研究に興味を 持つ。情報処理学会会員。

朝 倉 宏一

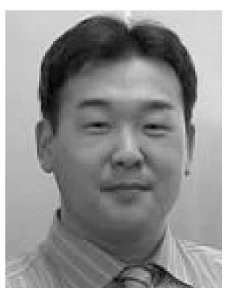

(非会員) 1992 年 名古屋大学 工学部 情報工学 科 卒業。1994 年 同大学大学院 工学研究科情報 工学専攻 博士課程前期課程 修了。1995 年 同大 学院 工学研究科情報工学専攻 博士課程後期課程 中途退学。同年 同大学院 工学研究科 情報工学専 攻 助手。2003 年 同大学 工学部電気電子 ·情報 工学科 助教授。現在，同大学 評価企画室 准教授。 博士 (工学)。計算機クラスタ環境における並列 処理，アドホック・ネットワーク等に興味を持つ。情報処理学会，電 子情報通信学会各会員。
渡 邊 豊 英 （正員） 1972 年 京都大学 理学部 卒業。1974 年

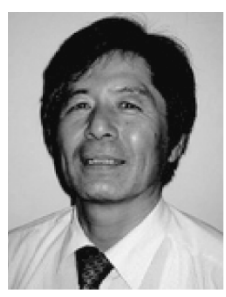
同大学院 工学研究科 数理工学専攻 修士課程修 了。1975 年 同博士課程 中途退学。同年 京都大 学 大型計算機センター助手。1987 年 名古屋大学 工学部 情報工学科 助教授。現在同大学大学院 情 報科学研究科 社会システム情報学専攻 教授。京 都大学工学博士。知識/データ工学, 協調学習環 境，並列 ·分散処理，文書理解，図形解釈等に興 味を持つ。情報処理学会, 電子情報通信学会, 日本ソフトウェア科学 会, 人工知能学会, 教育システム情報学会, 日本データベース学会, ACM, IEEE Computer Society, AAAI, AACE, KES International 各会員。 